\title{
Sucrose phosphate synthase (SPS), sucrose synthase (SUS) and their products in the leaves of Miscanthus $\times$ giganteus and Zea mays at low temperature
}

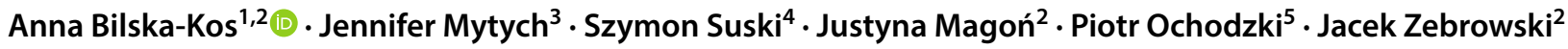

Received: 11 April 2020 / Accepted: 8 July 2020 / Published online: 16 July 2020

(c) The Author(s) 2020

\begin{abstract}
Main conclusion The changes in the expression of key sugar metabolism enzymes (SPS and SUS), sucrose content and arrangement of chloroplast starch may play a significant role in the cold response in M. giganteus and maize plants.
\end{abstract}

\begin{abstract}
To understand the mechanism of the chilling-response of two closely-related $\mathrm{C}_{4}$ plants, we investigated the changes in the expression of sucrose phosphate synthase (SPS) and sucrose synthase (SUS) as well as changes in their potential products: sucrose, cellulose and starch in the leaves of Miscanthus $\times$ giganteus and Zea mays. Low temperature $\left(12-14{ }^{\circ} \mathrm{C}\right)$ increased SPS content in Miscanthus (MG) and chilling-sensitive maize line (Zm-S), but not in chilling-tolerant one (Zm-T). In Zm-S line, chilling also caused the higher intensity of labelling of SPS in the cytoplasm of mesophyll cells, as demonstrated by electron microscopy. SUS labelling was also increased by cold stress only in MG plants what was observed in the secondary wall between mesophyll and bundle sheath cells, as well as in the vacuoles of companion cells. Cold led to a marked increase in total starch grain area in the chloroplasts of $\mathrm{Zm}-\mathrm{S}$ line. In turn, Fourier transform infrared spectroscopy (FTIR) showed a slight shift in the cellulose band position, which may indicate the formation of more compact cellulose arrangement in $\mathrm{Zm}-\mathrm{T}$ maize line. In conclusion, this work presents new findings supporting diversified cold-response, not only between two $\mathrm{C}_{4}$ plant species but also within one species of maize.
\end{abstract}

Keywords Cellulose $\cdot$ Immunolocalization $\cdot$ Starch grains $\cdot$ Sucrose $\cdot$ Sugar metabolism

Communicated by Dorothea Bartels.

Anna Bilska-Kos

a.bilska@ihar.edu.pl

1 Department of Plant Biochemistry and Physiology, Plant Breeding and Acclimatization Institute, National Research Institute, Radzików, 05-870 Błonie, Poland

2 Department of Plant Physiology and Ecology, Institute of Biology and Biotechnology, University of Rzeszow, Aleja Rejtana 16c, 35-959 Rzeszow, Poland

3 Department of Animal Physiology and Reproduction, Institute of Biology and Biotechnology, University of Rzeszow, Werynia 2, 36-100 Kolbuszowa, Poland

4 Laboratory of Electron Microscopy, Nencki Institute of Experimental Biology of Polish Academy of Sciences, 3 Pasteur Str, 02-093 Warsaw, Poland

5 Department of Plant Pathology, Plant Breeding and Acclimatization Institute, National Research Institute, Radzików, 05-870 Błonie, Poland

\author{
Abbreviations \\ FTIR Fourier transform infrared spectroscopy \\ MG Miscanthus $\times$ giganteus \\ SPS Sucrose phosphatate synthase \\ SUS1 Sucrose synthase 1 \\ $\mathrm{Zm}$-S Chilling-sensitive maize line \\ $\mathrm{Zm}-\mathrm{T}$ Chilling-tolerant maize line
}

\section{Introduction}

Sucrose phosphate synthase (SPS, EC.2.4.1.14) and sucrose synthase (SUS, EC.2.4.1.13) are key enzymes in the sugar metabolic pathways in the plants. SPS catalyzes the conversion of fructose-6-phosphate and uridine diphosphateglucose (UDP-glucose) into sucrose-6-phosphate which is a substrate in the synthesis of sucrose (Winter and Huber 2000; Chen et al. 2005). SUS catalyzes the conversion of sucrose and nucleoside diphosphate into the corresponding nucleoside diphosphate-glucose and fructose, and provides 
substrates for cellulose and starch biosynthesis: UDP-glucose and adenosine diphosphate-glucose (ADP-glucose) (Amor et al. 1995; Haigler et al. 2001; Baroja-Fernández et al. 2009).

SPS and SUS exist in many isoforms which may play various functional roles and be specialized in different tissues and stages of development. In addition, the activity and the localization of these enzymes can be controlled by reversible protein phosphorylation through the calcium-dependent kinases (CPDKs) and regulation mechanisms in individual species are varied (Huber and Huber 1996; Toroser and Huber 1997; Winter et al. 1997; Foyer et al. 1998; Duncan et al. 2006; Fedosejevs et al. 2014; Almadanim et al. 2017).

The determination of the functional roles of these isoforms is an ongoing area of research. Particularly, knowledge about the relationship of localization of individual forms of these enzymes and their role in plant responses to various stresses is highly desirable. It has been demonstrated for instance, that several maize SPS sequences were most strongly expressed in the leaves and less intensively in pollen and kernel, what was related to the reaction to different abiotic factors (Lutfiyya et al. 2007). In turn, in the columella cells of Arabidopsis thaliana roots, SPS isoforms support sucrose synthesis and stimulate starch synthesis in this tissue and respond differentially to the osmotic stress (Solís-Guzmán et al. 2017). In the source leaves of Nicotiana tabacum, the differential expression of three SPS isoforms revealed their involvement in the starch mobilization during the dark period (Chen et al. 2005). Similarly, four SPS isoforms localized in source leaves of Arabidopsis thaliana plants can play a role in dark respiration via enhancement of starch turnover (Bahaji et al. 2015).

SUS isoforms have been found in the different subcellular localizations: in vacuoles (Etxeberria and Gonzalez 2003), in plastids (Núñez et al. 2008), in mitochondria (Subbaiah et al. 2006), in the cytosol (Baroja-Fernández et al. 2009) as soluble enzyme and also in a membrane-bound form (Winter et al. 1997), and in the different areas of the cell wall (Salnikov et al. 2003; Persia et al. 2008). The different localization of individual SUS isoforms can promote the membraneassociated or cytosolic sucrose degradation which may result in the further type of carbon utilization path, i.e., cellulose or starch synthesis what can be additionally regulated by various stress factors. For instance, SUS localized in the plasma membrane in the developing cotton fibers can utilize carbon directly from sucrose to cellulose and/or callose synthases (Amor et al. 1995). In maize, the specificity of the function of individual SUS isoforms in both cytoplasmic and membrane-associated sucrose degradation was emphasized (Duncan et al. 2006). Also, in hexaploid wheat, the two types of SUS genes were differentially expressed in the endosperm, leaves and roots in response to anaerobiosis, light conditions and cold shock (Maraña et al. 1990).
The effect of low temperature on SPS and SUS activity has been studied in various approaches, mainly in $\mathrm{C}_{3}$ plants, by determination of changes in the expression of the genes and/or proteins as well as by analysis of sucrose and starch content. In general, during cold-response of plants, an increase in sucrose level is widely observed (reviewed by Sage and Kubien 2007). In the leaves of cold-treated spring and winter wheat, an increase in sucrose amount was noted, but these plants were not capable of adjusting the SPS and SUS activity to stress conditions (Savitch et al. 2000). Similarly, low temperature caused disorders in the development of wheat spikelets and florets via sucrose over-accumulation as well as changes in enzymes activity and gene expression associated with sucrose metabolism (Zhang et al. 2019). In the chillingsensitive accession of Arabidopsis plants, sucrose synthesis is indicated as a metabolic 'bottleneck' in response to cold conditions (Nägele et al. 2012). Guy et al. (1992) suggested that the increase in SPS activity and sucrose level in spinach leaves at low temperature is one of the adaptive mechanism elements manifested by the accumulation of compounds with cryoprotectant properties.

Following the above literature data, the presented studies on the expression of key plant sugar metabolism enzymes, their (sub) cellular localization and their potential products in cold-stressed $\mathrm{C}_{4}$ plants seem to be an important and original research approach. Our earlier studies support this approach, where diverse physiological, anatomical and biochemical responses to cold of Miscanthus and maize plants were found, including the changes in the composition of the neutral cell wall polysaccharides (Bilska-Kos et al. 2018). The results may suggest that the activity of the key enzymes in sugar metabolism can play a crucial role in $\mathrm{C}_{4}$ plants response to chilling. The aim of the present work was to verify the hypothesis that low temperature affects the abundance and/or localization of SPS and SUS1, as well as the organization of their potential products-sucrose, cellulose and starch. For this purpose, Western blotting and electron microscopic immunolocalization of these enzymes were performed. We analyzed the sucrose level using gas chromatography, as well as the cellulose organization by infrared spectroscopy (FTIR) in the leaf cell wall of the tested plant species. We also discuss the possible importance of the changes in the arrangement of starch grains in the chloroplasts in the context of the response to cold in the tested plants. Our work will provide valuable, previously unknown information about cold tolerance/sensitivity mechanism of $\mathrm{C}_{4}$ plant. 


\section{Materials and methods}

\section{Plant material and growth conditions}

The leaves of Miscanthus $\times$ giganteus (MG) and two maize lines (Zea mays L.): chilling-tolerant S68911 (Zm-T) and chilling-sensitive B73 (Zm-S) were used as an experimental material. The material was obtained from the following sources: Miscanthus rhizomes from the private plantation (Majdan Sieniawski, Poland), S68911 maize seeds from Plant Breeding Smolice Co., Ltd. (Smolice, Poland) and B73 maize seeds from USDA, ARS, Iowa State University (Ames, Iowa, USA). Both tested maize lines: S68911 and B73 are inbred lines belonging to $Z$. mays spp. indentata (dent type) representing Stiff Stalk Synthetic/Iodent pool and are characterized in the transcriptomic studies for their cold tolerance/sensitivity (Revilla et al. 2016; Sobkowiak et al. 2016). Plants were grown in a 5-L pots with a solid substrate in controlled conditions, in a growth chamber with parameters: $14 / 10 \mathrm{~h}$ light/darkness, irradiance $350 \mu \mathrm{mol}$ quanta $\mathrm{m}^{-2} \mathrm{~s}^{-1}$ at $24 / 22{ }^{\circ} \mathrm{C}$ (day/night) temperature. At the stage of the third fully developed leaf (ligular region present), the plants were transferred to low temperature $14 / 12{ }^{\circ} \mathrm{C}$ (day/night) for $28 \mathrm{~h}$. Chilling treatment was started at the beginning of the light period (chilling treatment period: $14 \mathrm{~h} /$ light, $10 \mathrm{~h} /$ dark, $4 \mathrm{~h} /$ light) and the control samples were taken $4 \mathrm{~h}$ after the light had been switched on. In each repetition of three independent experiments at least 6 plants per variant/per analysis type were used.

\section{Western-blot analyses}

The total protein from $M$. giganteus and maize leaves was extracted with $50 \mathrm{mM}$ Tris- $\mathrm{HCl} \mathrm{pH} 7.5,100 \mathrm{mM} \mathrm{NaCl}$, $0.2 \%$ Triton- $\mathrm{X}, 0.05 \% \beta$-mercaptoetanol, $6 \mathrm{M}$ urea, $2 \mathrm{mM}$ PMSF and denatured with $5 \times$ Laemmli Sample Buffer at $70{ }^{\circ} \mathrm{C}$ for $5 \mathrm{~min}$. Next, $30 \mu \mathrm{g}$ of protein samples were separated on $10 \%$ SDS-PAGE and electroblotted for $100 \mathrm{~min}$ to PVDF using tank transfer. Blots were blocked with 5\% milk in TBS-T for $30 \mathrm{~min}$ at room temperature (RT) with agitation. Blots were incubated with primary antibodies: anti-actin (A0480, Sigma-Aldrich), anti-SPS global (AS03 035A, Agrisera, Vännäs, Sweden) or anti-SUS1 (AS15 2830, Agrisera) at a dilution of 1:1000 overnight at $4{ }^{\circ} \mathrm{C}$ (antibodies diluted in 1\% BSA in TBS-T). The antibody solution was decanted and the blots were washed four times for $5 \mathrm{~min}$ in TBS-T at RT with agitation. Blots were incubated for $1 \mathrm{~h}$ at RT with agitation with secondary antibodies diluted in 1\% BSA in TBS-T: anti-mouse IgG horseradish peroxidase conjugated (A9044, Sigma
Aldrich) 1:40,000 (actin), anti-rabbit IgG horseradish peroxidase conjugated (AS09 602, Agrisera)-1:10,000 (SPS) and 1:40,000 (SUS1). The blots were washed as above and developed for 5 min with Clarity Max Western ECL Substrate (Bio-Rad Laboratories, Hercules, CA, USA). Exposure time was $30 \mathrm{~s}$ (for SPS) or $60 \mathrm{~s}$ (for SUS1).

\section{The preparation of material for electron microscopy}

Leaf samples were fixed in $4 \%$ paraformaldehyde with $0.5 \%$ glutaraldehyde in $0.1 \mathrm{M} \mathrm{PB}$ (phosphate buffer), $\mathrm{pH}$ 7.3 at $4{ }^{\circ} \mathrm{C}$ for $4 \mathrm{~h}$. After washing (PB) and dehydration (ethanol, 10-100\%) the material was embedded in LR White resin (Sigma-Aldrich) and polymerized for $168 \mathrm{~h}$ at $37^{\circ} \mathrm{C}$. Ultrathin sections $(80 \mathrm{~nm})$ mounted on nickel grids were obtained using a Leica Ultracut UTC ultramicrotome.

\section{Immunogold localization}

The immunolocalization of SPS and SUS was performed accordingly to the procedure previously described by BilskaKos et al. (2016b). Briefly, in the first step, the unspecific epitopes were blocked with $4 \%$ bovine albumin (BSA) in phosphate-buffered saline (PBS, $0.01 \mathrm{M}, \mathrm{pH} 7.3$ ). After washing in the washing mixture (1\% BSA/PBS), samples were incubated for $2 \mathrm{~h}$ with primary antibodies, for SPS: anti-SPS global (AS03 035A, Agrisera) or for SUS: antiSUS1 (AS15 2830, Agrisera) in the dilution: 1:100 (in PBS). For the negative control, the incubation with primary antibodies was omitted. After a series of washings-1\% BSA (in PBS), PBS and water-material was incubated for $2 \mathrm{~h}$ with secondary antibodies conjugated to $10 \mathrm{~nm}$ gold particles (goat anti-rabbit, Sigma-Aldrich). After washing (water) samples were contrasted with uranyl acetate (2.5\%) for $20 \mathrm{~min}$ and lead citrate $(0.04 \%)$ for $15 \mathrm{~min}$. The observations were performed using a transmission electron microscope (JEM 1400; Jeol Co., Tokyo, Japan) equipped with an 11-mpx MORADA G2 camera (EMSIS GmbH, Münster, Germany).

\section{Sucrose content}

The concentration of sucrose was determined as trimethylsilyl ether by gas chromatography with flame ionisation detection (GC-FID) according to Knudsen and Li (1991) with minor modifications. Briefly, $10 \mathrm{mg}$ of freeze-dried leaf material was extracted with $1 \mathrm{ml}$ of $80 \%(\mathrm{v} / \mathrm{v})$ ethanol and $100 \mu \mathrm{l}$ of internal standard (phenyl $\beta$-D-glucose, $5 \mathrm{mg} \mathrm{ml}^{-1}$ ) at $60{ }^{\circ} \mathrm{C}$ for $60 \mathrm{~min}$. with occasional shaking. After cooling and centrifugation, clear supernatant $(500 \mu \mathrm{l})$ was transferred to 4-ml vials and evaporated to dryness in stream on nitrogen. Dry residues were re-dissolved and derivatized 
to trimethylsilyl ether with $75 \mu \mathrm{l}$ of Sylon BTZ (SigmaAldrich). Next, after cooling, $1 \mathrm{ml}$ of isooctane and $2.5 \mathrm{ml}$ of deionised water were added and intensively shaken. After separation, the organic layer containing derivatized sucrose was transferred to $1.5 \mathrm{ml}$ vials and analyzed with GC-FID. Chromatographic analysis of sucrose was conducted on SRI 8610C gas chromatograph (SRI Instruments, Torrance, CA, USA), fitted with flame ionization detector (GC-FID) and HTA200 autosampler (HTA S.r.l., Brescia, Italy). Solutes were separated on BGB-5MS capillary column $(30 \mathrm{~m}$, $0.25 \mathrm{~mm} \mathrm{ID}, 0.25 \mu \mathrm{m}$ ) in temperature gradient (from $160{ }^{\circ} \mathrm{C}$ to $280{ }^{\circ} \mathrm{C}, 5{ }^{\circ} \mathrm{C} \mathrm{min}^{-1}$ ). Data acquisition and integration were conducted with PeakSimple ver. 454 integration programme. For the quantitative analysis of sucrose content the calibration curve was constructed, linear in the range of concentrations $0.1-1.0 \mathrm{mg} \mathrm{ml}^{-1}\left(r^{2}=0.999\right)$.

\section{Fourier transform infrared (FTIR) spectroscopy}

For the analysis of cellulose organization in leaves of $M$. giganteus and maize plants, the cell wall was isolated from frieze-dried leaves and purified from starch. The mid-infrared spectra were collected using Fourier transform infrared spectrometer (FTIR) Nicolet iZ 10 module (Thermo Fisher Scientific) and the ATR accessory equipped with a diamond crystal. Interferograms (256) were gathered at the resolution of $4 \mathrm{~cm}^{-1}$ and co-added within the wavelength range between 4000 and $400 \mathrm{~cm}^{-1}$ using OMNIC (v. 8.1, Thermo Fisher Scientific) software. The spectra were normalised to the unit area $\left(1800-900 \mathrm{~cm}^{-1}\right)$ after the baseline correction and processed for analysis using the ChemoSpec (Hanson 2017) and the hyperSpecc (Beleites and Sergo 2018) packages in the R (R Core Team 2018).

\section{Starch grains organization}

Based on the electron microscope images, the percentage of the starch granules area in the total area of chloroplast was determined using iTEM software (Olympus Soft Imaging Solution). The analysis was performed on the chloroplasts of Kranz mesophyll (KMS) and bundle sheath cells (BS). For the quantitative analysis of starch grains, at least thirty KMS and BS cells per experimental variant were considered.

\section{Statistical analysis}

The analysis of significant differences between mean values was performed using two-way ANOVA followed by the pairwise multiple comparisons of means using 'post-hoc' Tukey's Honestly Significant Difference (HSD) test. Both main effects: the genotype (three levels) and the treatment (two levels) as well as the genotype $\mathrm{x}$ treatment interactions were taken into account in the model. For analysis of cellulose peak position in FTIR studies, additionally 95\% Confidence Intervals (CIs) were calculated. The differences were considered significant for $P$ value less than 0.05 . The analysis was performed using R programming (R Core Team 2018).

\section{Results}

\section{Western-blot analysis}

Western-blot analysis revealed no significant changes in the SPS relative expression between control (non-chilled) and chilled plants of Zm-T maize line (Fig. 1a), while in chilled plants of MG and Zm-S maize line significant changes in the SPS abundance compared to the control plants was noted $(P<0.001)$-about 1.5 -fold and twofold higher, respectively. In the case of SUS1, ANOVA showed no significant effect of the interaction for genotype: treatment $[F(2 ; 12)=2.73$; $P=0.11]$ (Fig. 1b).

\section{Immunogold localization of SPS and SUS}

In general, SPS visualized by gold particles was localized in the cytoplasm of mesophyll and bundle sheath cells of the leaves of both tested plant species (Fig. 2). In rare cases, single gold grains were also observed in other subcellular localizations (e.g., endoplasmic reticulum) and in other types of cells (e.g., vascular parenchyma), however, the signal intensity was very low, at the background level (data not shown). In MG plants, SPS was predominantly found in the mesophyll cells where single gold particles as well as clusters of grains were observed (Fig. 2a, b), whereas in both maize lines SPS epitopes were evenly distributed in the mesophyll and bundle sheath cells (Fig. 2d, e, g, h). Cold caused a marked increase in SPS labelling in the leaves of Zm-S maize line, particularly in the mesophyll cells (Fig. 2h). The negative control, where the incubation with primary antibodies was omitted, confirmed the correctness of the method used - no signal was observed in the leaves of MG (Fig. 2c) and both maize lines (Fig. 2f, i).

SUS1 was localized in different cell types and in various organelles in the leaves of both tested plant species (Fig. 3). This protein was mainly found along the plasma membrane in all types of cells tested (Fig. 3a-1), in the secondary wall (Fig. 3b-g, i, k), as well as in the cell wall areas near plasmodesmata (Fig. 3b, c, f, g), also at the endoplasmic reticulum (Fig. 3a, d, j), in the vacuole (Fig. 3d) and in the cytoplasm (Fig. 31). In MG and Zm-T plants, SUS1 was more frequently observed in the cell wall, especially at mesophyll/bundle sheath interface, including plasmodesmata areas - so-called 'pit fields' (Fig. 3b, c, f, g). In the case of MG plants, SUS1 was also found in the vacuoles of companion cells (Fig. 3d), while in the $\mathrm{Zm}$-S maize line 
Fig. 1 The relative expression of a sucrose phosphate synthase (SPS) and $\mathbf{b}$ sucrose synthase 1 (SUS1) in leaves of the control (white bars) and chilled (grey bars) plants of Miscanthus $\times$ giganteus (MG), chilling-tolerant (Zm-T) and chilling-sensitive maize line ( $\mathrm{Zm}-\mathrm{S})$. Representative immunoblots are reported. The normalization was performed relative to actin. a For SPS, there is a significant effect of genotype [ANOVA, $F(2 ; 12)=68.73 ; P<0.0001$ ], treatment [ANOVA, $F(1 ; 12)=90.83 ; P<0.0001$ ] and of the interaction of genotype: treatment [ANOVA, $F(2 ; 12)=5.14 ; P=0.024]$ ]. b For SUS1, there is a significant effect of genotype [ANOVA, $F(2 ; 12)=18.39$; $P=0.0002$ ], treatment [ANOVA, $F(1 ; 12)=17.10 ; P=0.0014$ ], yet there is no significant effect of the interaction of genotype: treatment [ANOVA, $F(2 ; 12)=2.73 ; P=0.11$ ]. Protein lysates separated during SDS-PAGE electrophoresis were obtained by pooling the leaf material from at least 6 plants for each treatment from three independent experiments $(n=3)$. Bars represent the means $\pm \mathrm{SD}$, asterisks indicating a significant effect of chilling (Tukey's HSD test): $* * * P \leq 0.001$

SUS1 labelling was more intense in the cell wall of companion cells (Fig. 3i), and at endoplasmic reticulum, particularly in the mesophyll cells (Fig. 3j), as well as in the cytoplasm of sieve elements (Fig. 31). Cold led to an increase in the SUS1 labelling in MG leaves in the secondary wall between mesophyll and bundle sheath (Fig. 3b vs. c) and in the vacuoles of companion cells (Fig. 3a vs. d). In both maize lines, such differences in the intensity of SUS1 labelling were not observed. Simultaneously, the negative control, where the incubation with primary antibodies was omitted, showed no labelling in the cellular components of the MG leaves (Fig. 3m) and both maize lines (Fig. 3n, o).

\section{Sucrose content}

Gas chromatography analysis revealed no significant changes in the sucrose content in the leaves of control and chilled plants of MG and Zm-T maize line (Fig. 4), whereas cold caused a significant increase by $78 \%$ in the sucrose amount in the $\mathrm{Zm}-\mathrm{S}$ maize line treated with low temperature $(P<0.001)$.

\section{FTIR spectroscopy}

Fourier transform infrared spectroscopy (FTIR) analysis, a technique sensitive both to biochemical profile (functional groups presence) and the chemical structure of the components, affected by non-covalent interactions was used to detect the potential modifications in the cellulose chain arrangement associated with the response to cold. Cellulose assigned infrared bands involve several frequency regions between the $600 \mathrm{~cm}^{-1}$ and $4000 \mathrm{~cm}^{-1}$ (Nelson and O'Connor 1964) among which one band specifically attributed to out-of-plane $\mathrm{O}-\mathrm{H}$ bending vibrations in cellulose is around $670 \mathrm{~cm}^{-1}$ (Kondo and Sawatari 1996). The spectra of both examined species for control and chilled plants trimmed to the region between 667 and $673.5 \mathrm{~cm}^{-1}$ are given in Fig. 5. The chilling caused a slight shift
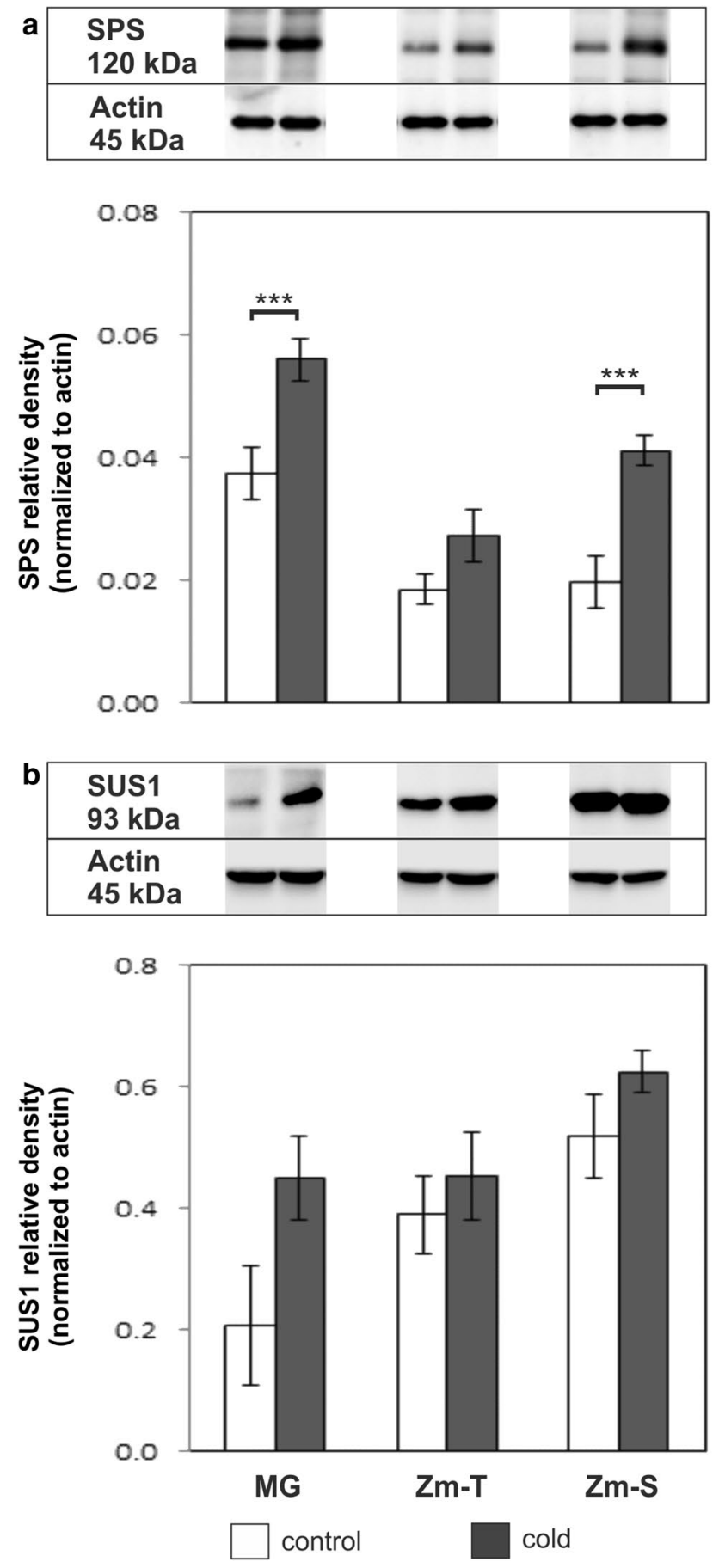

$(P=0.056)$ of the maximum absorbance from $669.69 \mathrm{~cm}^{-1}$ towards lower frequency $\left(669.21 \mathrm{~cm}^{-1}\right)$ in the plants of $\mathrm{Zm}-\mathrm{T}$ maize line. No such frequency shifts were observed either, for MG $(P=0.99)$ or $\mathrm{Zm}-\mathrm{S}$ line $(P=0.91)$.

\section{Starch grains}

The electron micrographs of the chloroplasts (Figs. 6, 7) were consistent with the general $\mathrm{C}_{4}$ plants anatomy 

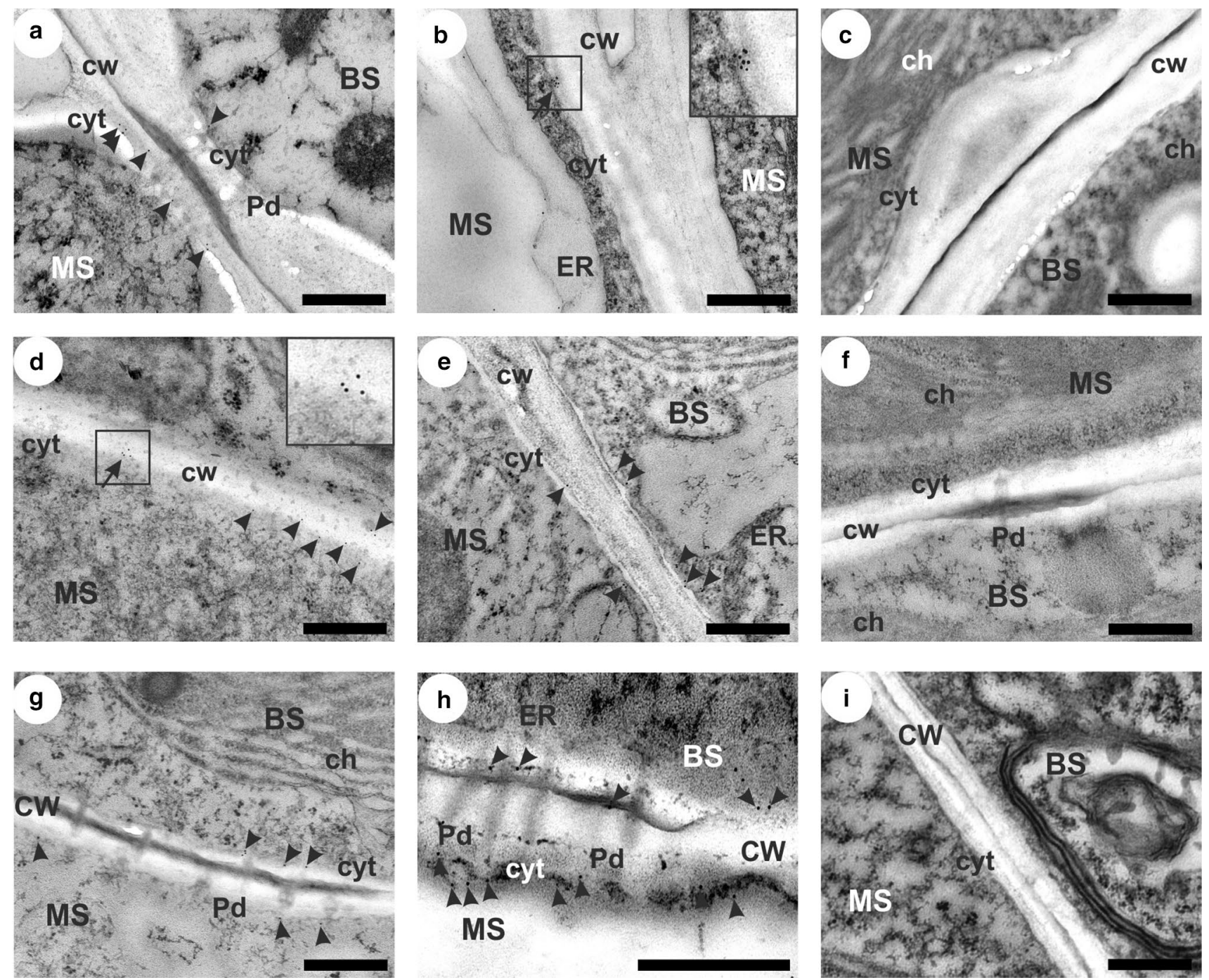

Fig. 2 Examples of localization of sucrose phosphate synthase (SPS) in the leaves of Miscanthus $\times$ giganteus, MG, chilling-tolerant, Zm-T and chilling-sensitive maize line, $\mathrm{Zm}$-S. Control (not-chilled plants) of MG (a), Zm-T line (d) and Zm-S maize line (g). Chilled-treated plants of MG (b), Zm-T line (e) and Zm-S maize line (h). Single gold particles (arrowheads) and the clusters of colloidal gold grains (arrows, more than three particles) visualizing anti-SPS antibody were mainly observed in the cytoplasm of mesophyll and bundle

(NADP-ME subtype) with a centrifugal arrangement of bundle sheath chloroplasts (von Caemmerer and Furbank 2003). In the mesophyll and bundle sheath chloroplasts of both tested plant species, starch grains were of different sizes and had various shapes, usually close to the oval (Figs. 6, 7). In the case of chilled plants of $\mathrm{Zm}-\mathrm{S}$ maize line, more starch grains were noted in the mesophyll chloroplasts compared to the control plants (Fig. 6f). Also, in the chloroplasts of bundle sheath cells a clear increase in the amount of starch grains was noted in this maize line under cold condition (Fig. 7f). The significant increase in total starch grain area of chloroplasts in both cell types was demonstrated in the sheath cells, including areas near plasmodesmata $(\mathbf{a}, \mathbf{g}, \mathbf{h})$. Note: more intense labelling in the cytoplasm of mesophyll cells of chilled plants of Zm-S maize line (h) compared to the control one (g). No signal was detected in the negative control, where the incubation with primary antibodies was omitted, in Miscanthus (c) and maize leaves (f, i). MS, mesophyll; BS, bundle sheath; VP, vascular parenchyma; ch, chloroplast; CW, cell wall; cyt, cytoplasm; ER, endoplasmic reticulum; Pd, plasmodesmata. Scale bar $=500 \mathrm{~nm}$

chilled plants of $\mathrm{Zm}-\mathrm{S}$ maize line $(P<0.001)$. An about fourfold and 1.8-fold higher amount of starch granules was noted for mesophyll and bundle sheath chloroplast, respectively (Fig. 8). In turn, in chilled plants of Zm-T maize line the increase in total starch grains area was observed only in the chloroplasts of mesophyll cells $(P=0.018)$. The cold did not cause changes in the amount of starch grains in the chloroplasts of both cell types in MG plants. 

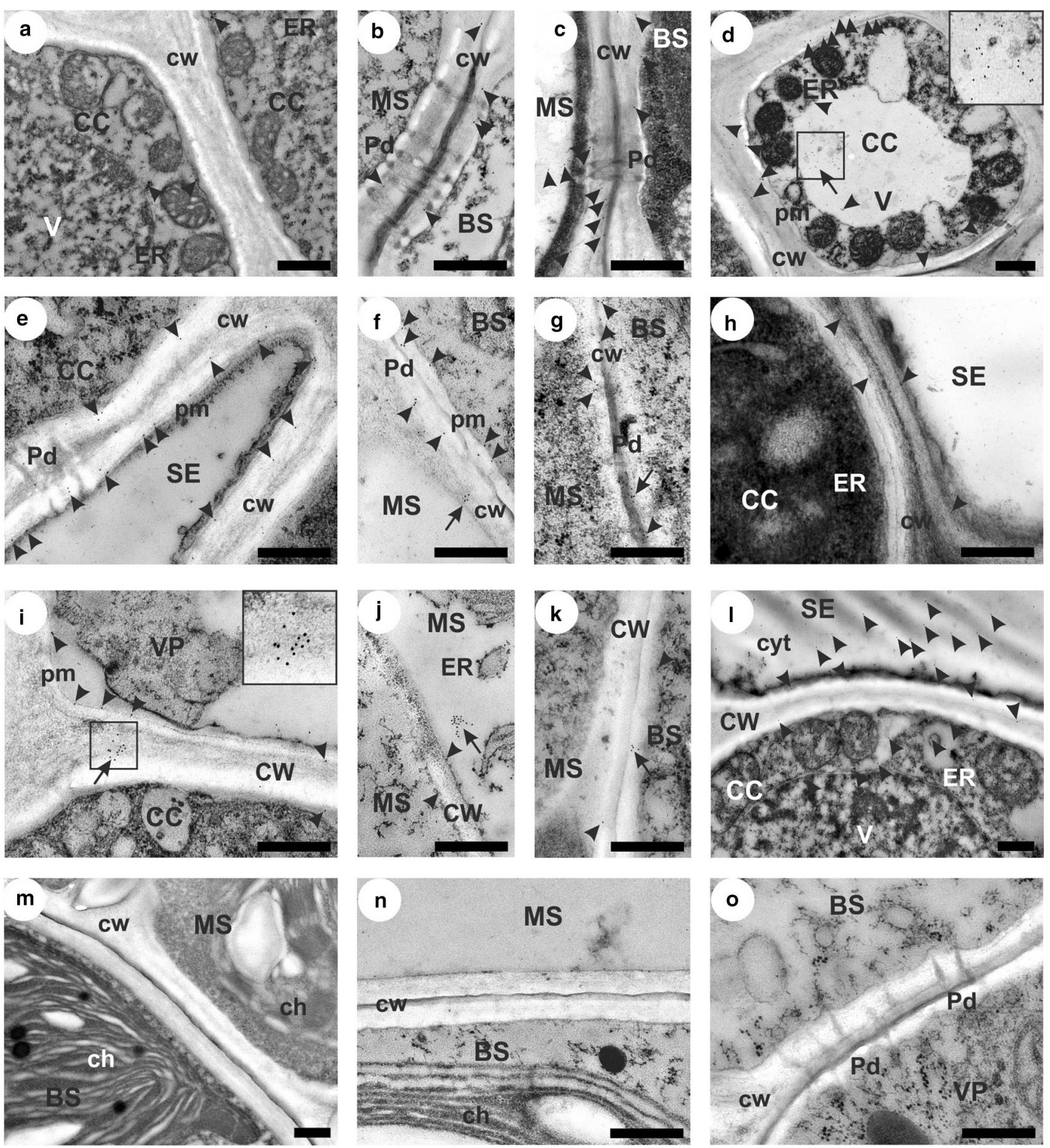

Fig. 3 Localization of synthase sucrose 1 (SUS1) in the leaves of Miscanthus $\times$ giganteus, MG, chilling-tolerant, $\mathrm{Zm}-\mathrm{T}$ and chillingsensitive maize line, Zm-S. Control (not-chilled plants) of MG (a, b), Zm-T line (e, f) and Zm-S maize line (i, j). Chilled-treated plants of MG (c, d), Zm-T line (g, h) and Zm-S maize line (k, l). Single gold particles (arrowheads) and the clusters of colloidal gold grains (arrows, more than three particles) visualizing anti-SUS1 antibody were mainly observed along the plasma membrane in all types of cells tested (a-l), in the secondary cell wall $(\mathbf{b}-\mathbf{g}, \mathbf{i}, \mathbf{k})$, including areas near plasmodesmata $(\mathbf{b}, \mathbf{c}, \mathbf{f}, \mathbf{g})$, at endoplasmic reticulum $(\mathbf{a}, \mathbf{d}, \mathbf{j})$, as well as in the vacuole (d) and cytoplasm (l). Note: more intense labelling in chilled plants of MG compared to the control one, in the secondary cell wall of mesophyll cells (b vs. c) and vacuole of companion cells (a vs. d). Negative control for Miscanthus (m) and maize leaves (n, o). MS, mesophyll; BS, bundle sheath; VP, vascular parenchyma; CC companion cell; SE, sieve element; ch, chloroplast; CW, cell wall; cyt, cytoplasm; ER, endoplasmic reticulum; pm, plasma membrane; Pd, plasmodesmata; V, vacuole. Scale bar $=500 \mathrm{~nm}$ 


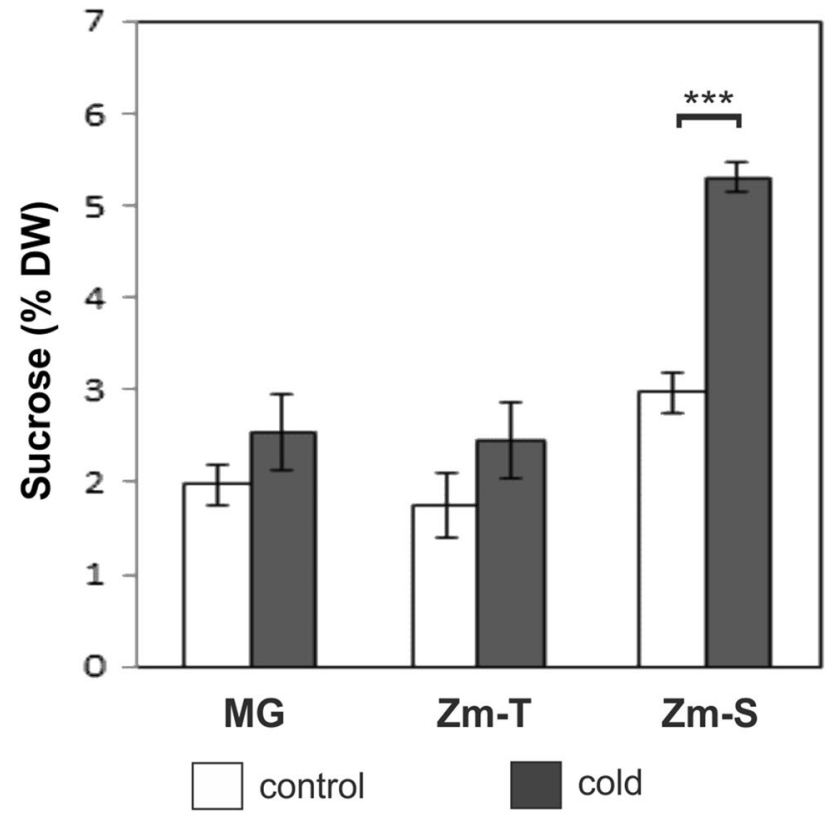

Fig. 4 The level of sucrose analyzed by GC in the leaves of the control (white bars) and chilled (grey bars) plants of Miscanthus $\times$ giganteus (MG), chilling-tolerant ( $\mathrm{Zm}-\mathrm{T})$ and chilling-sensitive maize line $(\mathrm{Zm}-\mathrm{S})$. The sucrose content is expressed as \% leaf dry weight (DW). The significant effect of genotype [ANOVA, $F(2 ; 12)=79.03$; $P<0.0001$ ], treatment [ANOVA, $F(1 ; 12)=66.89 ; P<0.0001$ ] and effect of the interaction of genotype: treatment were noted [ANOVA, $F \quad(2 ; 30)=14.76 ; \quad P<0.0001]$. Results represent six independent extractions $(n=6)$ with $80 \%(\mathrm{v} / \mathrm{v})$ ethanol. Bars represent the means $\pm \mathrm{SD}$, asterisks indicating a significant effect of chilling (Tukey's HSD test): $* * * P \leq 0.001$

\section{Discussion}

Sucrose phosphate synthase (SPS) is assumed to be a key regulator for controlling biosynthesis of sucrose in the source tissues; sucrose is then transported to the sink organs for the utilization, storage or as an element of the signalling pathway (Winter and Huber 2000). The accumulation of soluble sugars, including sucrose, is known as one of the mechanisms of plant adaptation to dehydration and freezing stress. Under these conditions, sugars as osmoprotectants may regulate the osmotic potential of cells, and can also stabilize membranes, through interaction with the lipid layer (reviewed by Sami et al. 2016).

In our work, the higher abundance of SPS (Fig. 1a) with more intense labelling in the cytoplasm of mesophyll cells (Fig. $2 \mathrm{~h}$ ) in the leaves of the chilled $\mathrm{Zm}$-S line reflected the increase in sucrose content in leaves of this maize line (Fig. 4). Similarly, in our previous studies, in another chilling-sensitive maize line the accumulation of sucrose under cold conditions has been noted (Bilska-Kos et al. 2017) which was probably caused by the inhibition of transport processes via closure of plasmodesmata in the

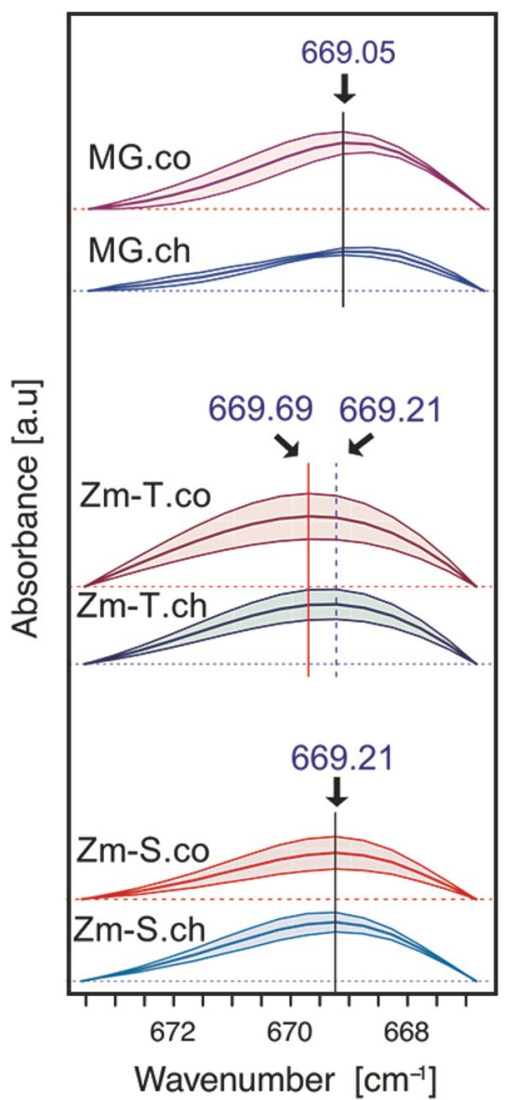

Fig. 5 Absorbance of infrared spectra (means $\pm 95 \%$ confidence intervals) of cell wall isolated from the $3^{\text {rd }}$ leaves in the control (red/.co) and chilled (blue/.ch) plants of Miscanthus $\times$ giganteus (MG), chilling-tolerant $(\mathrm{Zm}-\mathrm{T})$ and chilling-sensitive maize line $(\mathrm{Zm}-\mathrm{S})$. The spectra are given for the region between c. 667 and $673.5 \mathrm{~cm}^{-1}$ wavelength assigned to the $\mathrm{OH}$ out-of-plane bending vibrations in cellulose. The significant genotype effect for the peak position [ANOVA, $(F(2 ; 29)=13.571 ; P<0.01)]$, and the significant genotype: treatment interaction $(F(2 ; 29)=4.009 ; P=0.029)$ were noted. The confidence intervals from Tukey.HSD post-hoc test for estimated difference of means between the maximum peak position of chilled and control plants were as follows: MG [95\% CIs $(-0.2739,0.3772), P=0.99]$, $\mathrm{Zm}-\mathrm{T}[95 \%$ CIs $(-0.0055,0.6455), P=0.056]$ and $\mathrm{Zm}-\mathrm{S}[95 \%$ CIs $(-0.2295,0.4534), P=0.91]$. Positions of mean maximum absorbances are marked with arrows. The spectra are shifted in absorbance for clarity

photosynthetic pathway (Bilska and Sowiński 2010). It has been previously found that the carbon transfer between the $\mathrm{C}_{3}$ and $\mathrm{C}_{4}$ cycle in $\mathrm{C}_{4}$ plants is slower at low temperature (Long 1983), and the transport of sucrose and other lowmolecular compounds in the ER cylinder of plasmodesmata is less efficient (Gamalei et al. 1994). In this scenario, the sucrose which was unable to pass through blocked plasmodesmata to the phloem loading site, i.e. to the complex of companion cells/sieve elements, was accumulated in the Kranz mesophyll, bundle sheath and vascular parenchyma cells where lower osmotic potential was observed (BilskaKos et al. 2017). This reaction occured in a relatively short 
Fig. 6 Ultrastructure of mesophyll chloroplasts with starch grains arrangement in the control (a, c, e) and chilled (b, d, f) plants of Miscanthus $\times$ giganteus (MG), chilling-tolerant $(\mathrm{Zm}-\mathrm{T})$ and chilling-sensitive maize line (Zm-S). In the chilled leaves of $\mathrm{Zm}-\mathrm{S}$ line (f) more starch grains are observed than in the control plants of this maize line (e). Ch, chloroplast; $\mathrm{CW}$, cell wall; $\mathrm{S}$, starch grain. Scale bar $=1 \mu \mathrm{m}$
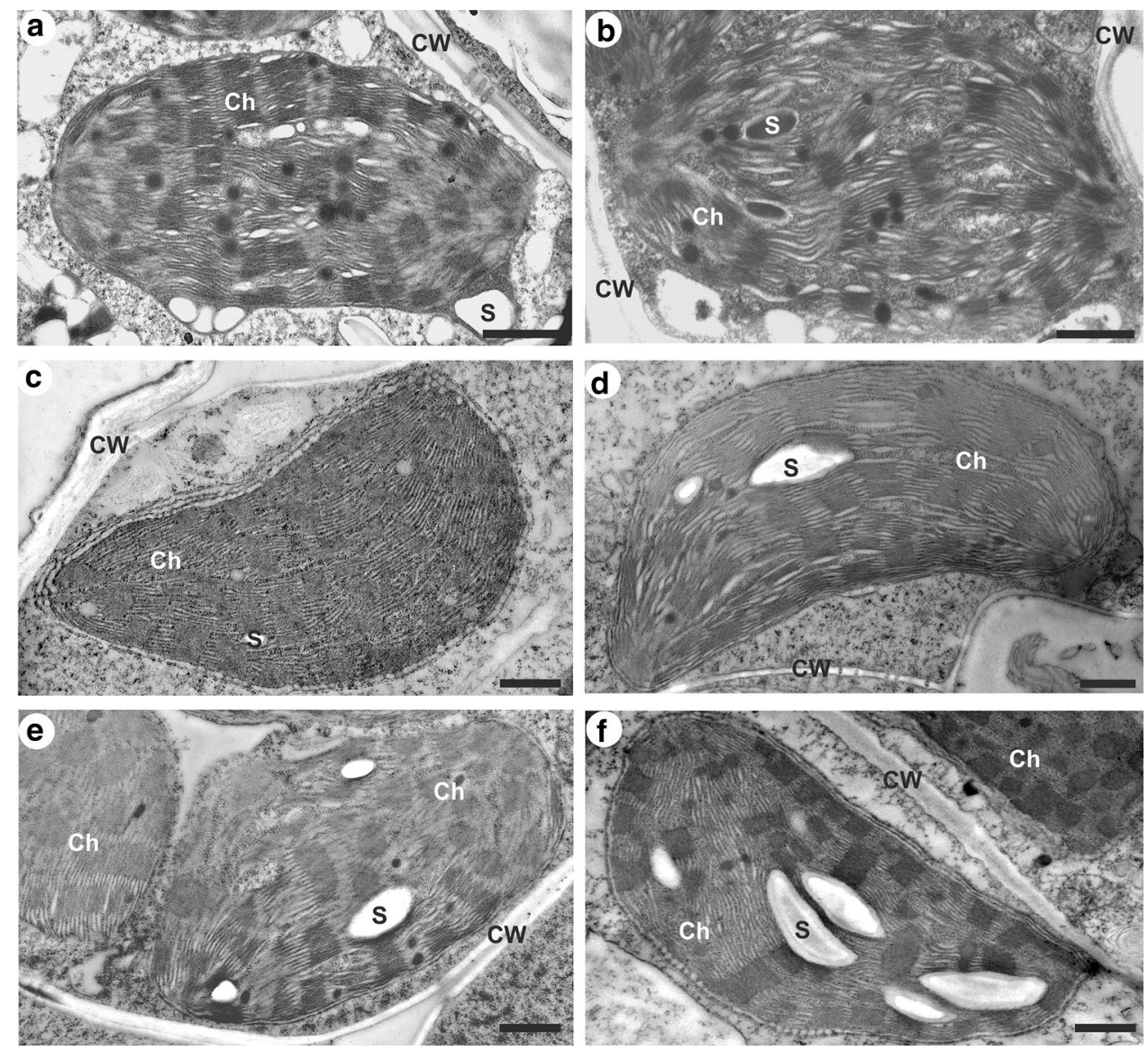

time-just after $1 \mathrm{~h}$ of chilling, the closure of plasmodesmata was observed (Bilska and Sowiński 2010). Hence, it can be assumed that the rapid accumulation of sucrose observed in chilled plants of Zm-S maize line (Fig. 4) is a direct response to cold stress associated with the blocking of intercellular transport rather than the element of the adaptation to low-temperature conditions. In contrast, the increase in sucrose content under prolonged chilling (7 days) in both, chilling-tolerant and chilling-sensitive maize lines, can be considered as a manifestation of the ability to adapt to moderate cold conditions of both maize lines (Sowiński et al. 1999). It should be noted, that in some cases the overaccumulation of sucrose is not accompanied by a high abundance of SPS, and conversely. For instance, the increase in the sucrose content in maize leaves was not a result of the changes in SPS activity (Lunn and Hatch 1997). Similarly, knockout mutants of rice (OSSPS1) with reduced SPS activity showed no changes in the content of sugars, including starch/sucrose ratio and in the overall plant growth (Hashida et al. 2016). In addition, mRNA levels of two SPS forms in rice were negatively correlated with sucrose content (Okamura et al. 2011). However, the higher SPS protein expression in cold-acclimated barley plants was associated with freezing tolerance in tested genotypes (Rapacz et al. 2008).
Hence, it may be possible that under certain conditions, a higher SPS protein level provides sufficient sucrose synthesis, even at very low enzyme activity.

On the other hand, the part of the sucrose pool synthetized by SPS may be used for the production of the cellulose and starch by SUS (Im 2004). This may partly explain the high SPS level in chilled MG plants compared to the control ones (Fig. 1a) with simultaneously observed unchanged level of sucrose in this plant species (Fig. 4). It is also possible, that another gene family may regulate SPS activity in Miscanthus than in maize because such diversity in gene expression pattern has been demonstrated for several species within grasses (Castleden et al. 2004).

The second enzyme tested in this work, sucrose synthase (SUS), is most often considered as an enzyme challenging UDP-glucose to cellulose synthesis, particularly in the stage of intensive secondary cell wall formation (reviewed by Haigler et al. 2001). In our previous work, cold led to the reduction of the crystalline cellulose content but, at the same time, caused the increase in the cell wall thickness of bundle sheath cells in the MG plants (Bilska-Kos et al. 2018). In the present work, the increase in SUS1 labelling in the secondary cell wall between mesophyll and bundle sheath cells (Fig. 3c) may be evidence for more intensified activity 

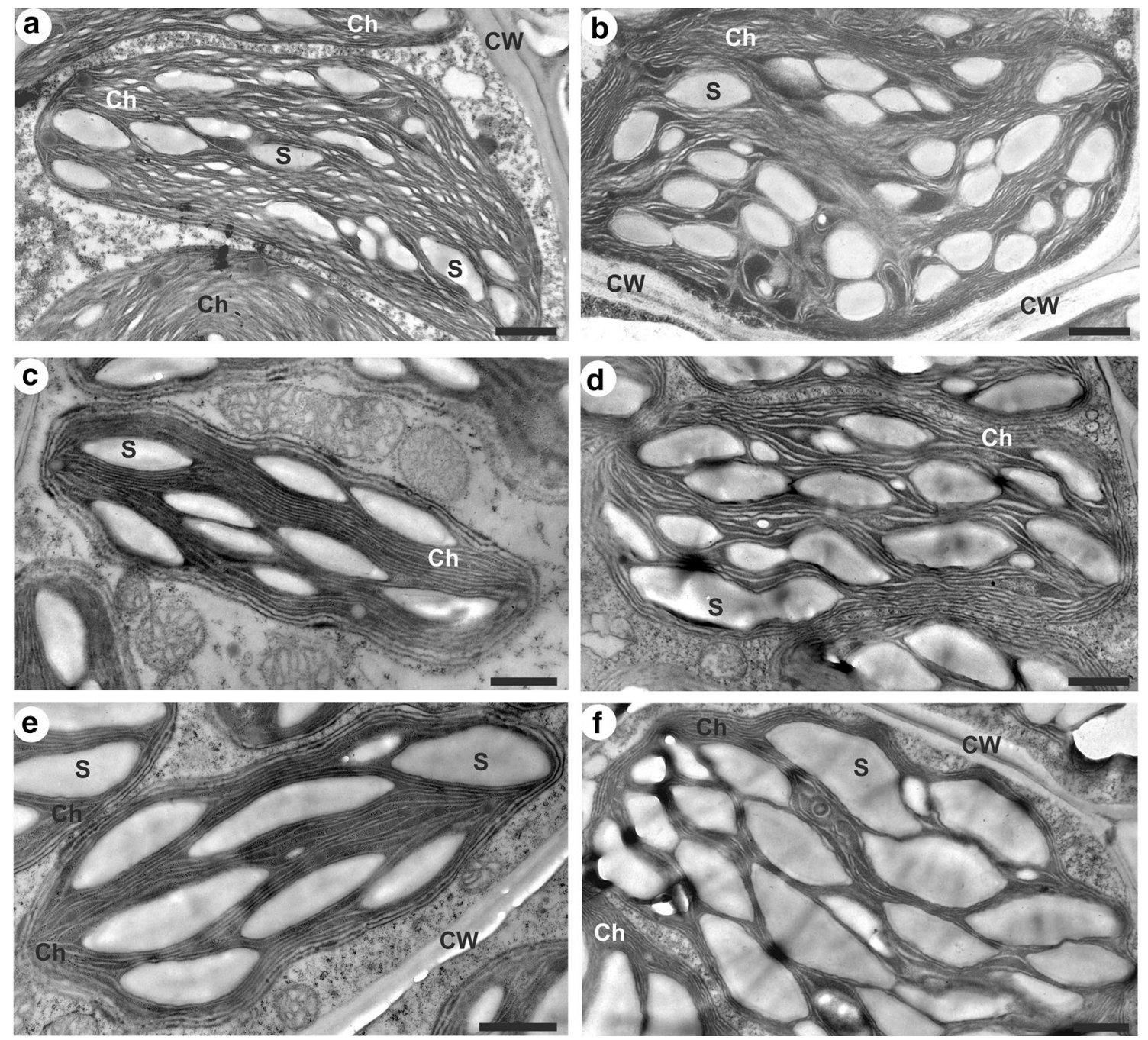

Fig. 7 Ultrastructure of bundle sheath chloroplasts with starch grains arrangement in the control $(\mathbf{a}, \mathbf{c}, \mathbf{e})$ and chilled $(\mathbf{b}, \mathbf{d}, \mathbf{f})$ plants of Miscanthus $\times$ giganteus $(\mathrm{MG})$, chilling-tolerant $(\mathrm{Zm}-\mathrm{T})$ and chilling-sen-

sitive maize line $(\mathrm{Zm}-\mathrm{S})$. Note the extensive starch grains filling in the chloroplast of chilled plants of $\mathrm{Zm}-\mathrm{S}$ maize line (f). Ch, chloroplast; $\mathrm{CW}$, cell wall; $\mathrm{S}$, starch grain. Scale bar $=1 \mu \mathrm{m}$

of this enzyme in these local (micro) areas. Similarly, higher activity of SUS enzymes in hybrid poplar plants resulted in a thicker cell wall of xylem and greater crystallinity of this wall type, which consequently led to increased wood density (Coleman et al. 2009). It is also possible that SUS1 has a predominant role during increased energy demand under abiotic stress in Miscanthus plants, due to the fact, that different genes encoding various SUS isoforms may have specialized function depending on the plant species, developmental stage or external factors (Wang et al. 2015). On the other hand, it should be realized that the increase in SUS1 abundance, which was 'captured' on the microscopic images may have temporal character during a dynamic carbon partitioning process.

The FTIR spectroscopy quantitative analysis showed a slight shift towards lower values at about $670 \mathrm{~cm}^{-1}$, attributed to cellulose (Kondo and Sawatari 1996; Abidi et al. 2014), exclusively for the Zm-T maize line in the response to low temperature (Fig. 5). This indicates an increase in the $\mathrm{O}-\mathrm{H} \cdots \mathrm{O}$ hydrogen bonding between cellulose chains (Kondo and Sawatari 1996; Ilharco et al. 1997) that may reflect the onset of formation of slightly more compact and/or more crystalline structure in $\mathrm{Zm}-\mathrm{T}$ maize line.

In turn, the relatively high intensity of SUS1 labelling in the phloem cells of the Zm-S line (Fig. 31) may be the result of the phloem loading inhibition observed in the other chilling-sensitive maize material (Bilska and Sowiński 2010), and may not be relevant for the synthesis of cell wall components. Such cellular localization of SUS may indicate the predominant role of this enzyme in the loading and unloading of sucrose in the phloem, which has been previously 

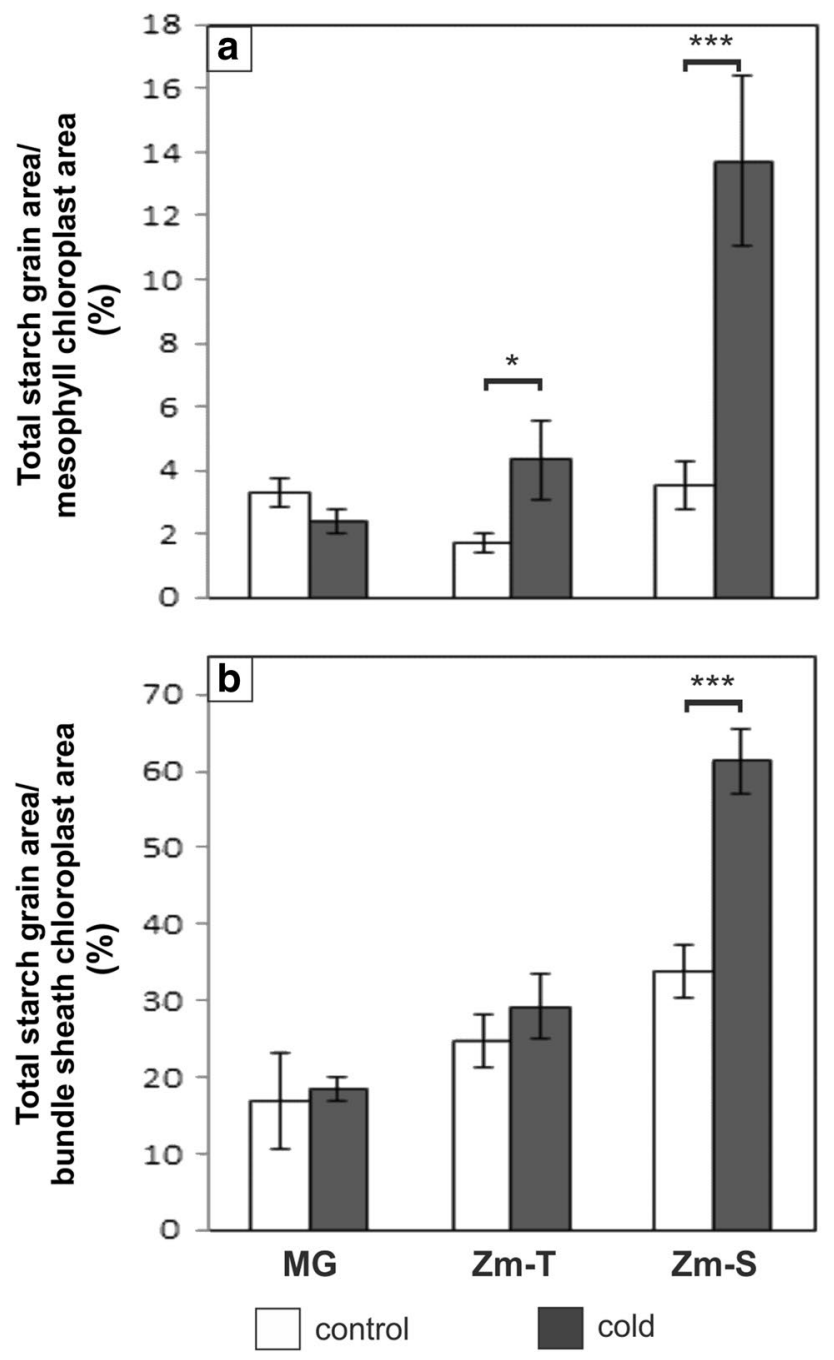

Fig. 8 Total starch grain area in the chloroplasts of mesophyll (a) and bundle sheath cells (b) in the control (white bars) and chilled (grey bars) plants of Miscanthus $\times$ giganteus (MG), chilling-tolerant $(\mathrm{Zm}-\mathrm{T})$ and chilling-sensitive maize line $(\mathrm{Zm}-\mathrm{S})$. Values are expressed as \% of total area of starch grain in the total area of chloroplast. a Significant effect of genotype [ANOVA, $F(2 ; 102)=73.45$; $P<0.0001$ ], treatment [ANOVA, $F(1 ; 102)=80.78 ; P<0.0001$ ] and of the interaction of genotype: treatment [ANOVA, $F(2 ; 102)=54.89$; $P<0.001$ ]. b Significant effect of genotype [ANOVA, $F$ $(2 ; 102)=153.35 ; P<0.0001$ ], treatment [ANOVA, $F(1 ; 102)=61.27$; $P<0.0001]$ and of the interaction of genotype: treatment [ANOVA, $F(2 ; 102)=31.41 ; P<0.0001]$. For each treatment, the total area of starch grain in the chloroplasts was measured from at least thirty Kranz mesophyll or bundle sheath cells from six plants with three independent experiments $(n=18)$. Bars represent the means \pm SD; asterisks indicating a significant effect of chilling (Tukey's HSD test): $* P \leq 0.05 ; * * * P \leq 0.001$

demonstrated in rice seeds (Wang et al. 1999), as well as in maize and citrus leaves (Nolte and Koch 1993).

In addition to the role in the cellulose synthesis, SUS participates in the supply of substrates such as ADP-glucose, for the starch synthesis. Under cold stress, the increase in starch content is mainly observed, however, this response may depend on other factors, i.a. experimental conditions (reviewed by Thalmann and Santelia 2017). This mechanism may be associated with e.g., cold-induced changes in the intra-/inter-cellular transport, in the phloem loading and in the long-distance transport on the path: source (leaves) sink (roots), as well as the modification of the osmotic/ water potential of cells (Gamalei et al. 1994; Čiamporová and Trgiňová 1996; Bilska and Sowiński 2010; Bilska-Kos et al. 2016b, 2017). The starch is primarily accumulated in chloroplasts and the consequence of both, direct and indirect (including changes in the starch grains organization) cold effects, on the structural modifications of chloroplasts have been widely reported (Čiamporová and Trgiňová 1996; Kutík et al. 2004; Skupień et al. 2017). Generally, the coldinduced starch accumulation in the chloroplasts is accompanied by the changes in the arrangement of thylakoids, in the amount of plastoglobuli and in granal organization (Čiamporová and Trgiňová 1996; Kutík et al. 2004). In our case, the marked increase in total starch grain area was observed in the $\mathrm{Zm}-\mathrm{S}$ maize line, in both mesophyll and bundle sheath chloroplasts (Figs. 6, 7, 8). Thus, it may be supposed that the changes in the structure of chloroplasts leading to disorders in the photosynthetic apparatus can affect photosynthesis and the transport of photosynthetic products, as has been previously observed for other chilling-sensitive maize line (Bilska and Sowiński 2010; Bilska 2013; BilskaKos et al. 2016a). The effect of cold on the photosynthetic apparatus was also visible in the 5th maize leaf-the starch grains were noted in bundle sheath chloroplasts in the leaves of the chilling-sensitive line (Sowiński et al. 2005), what has been confirmed by gas-liquid chromatography in another work (Sowiński et al. 1999). These results were explained by deepening inorganic phosphorus deficiency in this maize line under cold conditions. In turn, in the other work, starch grains completely disappeared after 7 days of cold treatment at $6{ }^{\circ} \mathrm{C}$ in the chloroplast of bundle sheath cells in the leaves of chilling-sensitive maize line (Penjalinan) while in chilling-tolerant line (Z7) number of starch grains was increased (Čiamporová and Trgiňová 1996). Among different maize lines perhaps a variation in the metabolism of starch under cold stress conditions might occur, highly specific to each genotype. On the other hand, the accumulation of starch in the chloroplasts, as an energy storage material, may be a manifestation of the ability to adapt to the stress conditions. For instance, the up-regulated genes related to starch metabolism could protect the young shoots of tea (Camellia sinensis) against cold-induced damages and participate in the general process of the acclimatization to low temperature (Hao et al. 2018). In turn, in Arabidopsis the cold-enhanced breakdown of starch was associated with freezing tolerance manifested by starch-depended maltose accumulation which can protect the photosynthetic electron 
transport chain during stress (Kaplan and Guy 2005). Thus, it is possible that the observed in this study slight increase in the total starch grain area in the mesophyll chloroplasts of $\mathrm{Zm}$-T maize line (Fig. 8) had no significant effect on these organelles structure (Fig. 6d), and may indicate the activation of certain defensive paths of the adaptive mechanism to cold stress in this maize line.

\section{Conclusion}

This work demonstrated that, in both the most chilling-tolerant (MG) and the least chilling-tolerant genotype ( $\mathrm{Zm}-\mathrm{S}$ maize line), SPS content was increased at low temperature, but this was most likely associated with different pathways of cold acclimation. In the case of $\mathrm{Zm}-\mathrm{S}$ line, the higher abundance of SPS resulting in the increase in sucrose level, as well as the increase in total starch grain area in the chloroplasts, may indicate the changes in the general sugar metabolism under cold conditions. These changes may be associated with the photosynthesis and transport process inhibition, as well as osmotic potential modifications (Bilska and Sowiński 2010; Bilska-Kos et al. 2017). Furthermore, the higher abundance of SPS in the chilled leaves of MG plants could lead to increased supply of sucrose and its immediate use by SUS for the synthesis of cell wall material. This may be related to local remodeling of cellulose as evidenced by the increase in the SUS1 labelling intensity in the cell wall between mesophyll and bundle sheath cells of chilled MG plants. Further research, including integrated analyses at physiological, biochemical and molecular levels of other enzymes involved in the sugar metabolism, can bring new elements to the 'puzzle' that forms the overall cold-response of $\mathrm{C}_{4}$ plants.

\section{Author contribution statement}

$\mathrm{AB}-\mathrm{K}$ defined the research problem, designed the experiments and wrote the manuscript. JMy performed Westernblot experiments and the analysis of their results. AB-K prepared the material for electron microscopy, carried out immunogold experiments and microscopic observations. SS performed a quantitative analysis of starch grains. JMa prepared samples for gas-chromatography analysis and carried out gas-chromatography experiments. PO performed gas-chromatography analysis. AB-K and JZ performed FTIR measurements. JZ analyzed FTIR spectra and wrote FTIR section. All authors read and approved the final version of the manuscript.
Acknowledgements The authors wish to thank Reviewers and Editors for valuable remarks that have greatly improved the paper. We thank Prof. Józef Adamczyk (Plant Breeding Smolice Co., Ltd., Poland) for providing S68911 maize seeds, Mr. Mark J. Millard (USDA-ARS, Iowa State University, USA) for providing B73 maize seeds and Mr. Marian Pokrywka (Majdan Sieniawski, Poland) for supply the Miscanthus rhizomes. We are grateful to Dr. Witold Wrzask (Kolbuszowa Forest Inspectorate, Poland) for sharing the cold store for Miscanthus rhizomes storage. TEM observations were performed at the Laboratory of Electron Microscopy, Nencki Institute of Experimental Biology, PAS, Warsaw (Poland). This work was financially supported by the grant FUGA2 No DEC-2013/08/S/NZ9/00870 from the National Science Centre (Poland) and by statutory funds from Ministry of Science and Higher Education (Poland).

Open Access This article is licensed under a Creative Commons Attribution 4.0 International License, which permits use, sharing, adaptation, distribution and reproduction in any medium or format, as long as you give appropriate credit to the original author(s) and the source, provide a link to the Creative Commons licence, and indicate if changes were made. The images or other third party material in this article are included in the article's Creative Commons licence, unless indicated otherwise in a credit line to the material. If material is not included in the article's Creative Commons licence and your intended use is not permitted by statutory regulation or exceeds the permitted use, you will need to obtain permission directly from the copyright holder. To view a copy of this licence, visit http://creativecommons.org/licenses/by/4.0/.

\section{References}

Abidi N, Cabrales L, Haigler CH (2014) Changes in the cell wall and cellulose content of developing cotton fibers investigated by FTIR spectroscopy. Carbohydr Polym 100:9-16. https://doi. org/10.1016/j.carbpol.2013.01.074

Almadanim MC, Alexandre BM, Rosa MTG, Sapeta H, Leitao AE, Ramalho JC, Lam TT, Negrao S, Abreu IA, Oliveira MM (2017) Rice calcium-dependent protein kinase OsCPK17 targets plasma membrane intrinsic protein and sucrose-phosphate synthase and is required for a proper cold stress response. Plant Cell Environ 40:1197-1213. https://doi.org/10.1111/pce.12916

Amor Y, Haigler CH, Johnson S, Wainscott M, Delmer DP (1995) A membrane-associated form of sucrose synthase and its potential role in synthesis of cellulose and callose in plants. Proc Natl Acad Sci USA 92:9353-9357. https://doi.org/10.1073/pnas.92.20.9353

Bahaji A, Baroja-Fernández E, Ricarte-Bermejo A, Sánchez-López ÁM, Muñoz FJ, Romero JM, Ruiz MT, Baslam M, Almagro G, Sesma MT, Pozueta-Romero J (2015) Characterization of multiple SPS knockout mutants reveals redundant functions of the four Arabidopsis sucrose phosphate synthase isoforms in plant viability, and strongly indicates that enhanced respiration and accelerated starch turnover can alleviate the blockage of sucrose biosynthesis. Plant Sci 238:135-147. https://doi.org/10.1016/j. plantsci.2015.06.009

Baroja-Fernández E, Muñoz FJ, Montero M, Etxeberria E, Sesma MT, Ovecka M, Bahaji A, Ezquer I, Li J, Prat S, Pozueta-Romero J (2009) Enhancing sucrose synthase activity in transgenic potato (Solanum tuberosum L.) tubers results in increased levels of starch, ADPglucose and UDPglucose and total yield. Plant Cell Physiol 50:1651-1662. https://doi.org/10.1093/pcp/pcp108

Beleites C, Sergo V (2018) hyperSpec: a package to handle hyperspectral data sets in R. R package version v0.99-20180627. https ://github.com/cbeleites/hyperSpec/releases/tag/v0.99-20180627. Accessed 28 June 2018 
Bilska A (2013) Regulation of intercellular transport through plasmodesmata under abiotic stresses. In: Sokołowska K, Sowiński $\mathrm{P}$ (eds) Symplasmic transport in vascular plants. Springer, NY, pp 83-100

Bilska A, Sowiński P (2010) Closure of plasmodesmata in maize (Zea mays) at low temperature: a new mechanism for inhibition of photosynthesis. Ann Bot 106:675-686. https://doi.org/10.1093/ aob/mcq169

Bilska-Kos A, Grzybowski M, Jończyk M, Sowiński P (2016a) In situ localization and changes in the expression level of transcripts related to intercellular transport and phloem loading in leaves of maize (Zea mays L.) treated with low temperature. Acta Physiol Plant 38:123. https://doi.org/10.1007/s11738-016-2151-5

Bilska-Kos A, Szczepanik J, Sowiński P (2016b) Cold induced changes in the water balance affect immunocytolocalization pattern of one of the aquaporins in the vascular system in the leaves of maize (Zea mays L.). J Plant Physiol 205:75-79. https://doi. org/10.1016/j.jplph.2016.08.006

Bilska-Kos A, Solecka D, Dziewulska A, Ochodzki P, Jończyk M, Bilski H, Sowiński P (2017) Low temperature caused modifications in the arrangement of cell wall pectins due to changes of osmotic potential of cells of maize leaves (Zea mays L.). Protoplasma 254:713-724. https://doi.org/10.1007/s00709-016-0982-y

Bilska-Kos A, Panek P, Szulc-Głaz A, Ochodzki P, Cisło A, Zebrowski J (2018) Chilling-induced physiological, anatomical and biochemical responses in the leaves of Miscanthus $\times$ giganteus and maize (Zea mays L.). J Plant Physiol 228:178-188. https://doi. org/10.1016/j.jplph.2018.05.012

Castleden CK, Aoki N, Gillespie VJ, MacRae EA, Quick WP, Buchner P, Foyer CH, Furbank RT, Lunn JE (2004) Evolution and function of the sucrose-phosphate synthase gene families in wheat and other grasses. Plant Physiol 135:1753-1764. https://doi. org/10.1104/pp.104.042457

Chen S, Hajirezaei M, Börnke F (2005) Differential expression of sucrose-phosphate synthase isoenzymes in tobacco reflects their functional specialization during dark-governed starch mobilization in source leaves. Plant Physiol 139:1163-1174. https://doi. org/10.1104/pp.105.069468

Čiamporová M, Trgiňová I (1996) Ultrastructure of chloroplasts in leaves and of plastids in root tips of two maize lines differing in chilling tolerance. Biologia 51:441-447

Coleman HD, Yan J, Mansfield SD (2009) Sucrose synthase affects carbon partitioning to increase cellulose production and altered cell wall ultrastructure. Proc Natl Acad Sci USA 106:13118-13123. https://doi.org/10.1073/pnas.0900188106

Duncan KA, Hardin SC, Huber SC (2006) The three maize sucrose synthase isoforms differ in distribution, localization, and phosphorylation. Plant Cell Physiol 47:959-971. https://doi.org/10.1093/ pcp/pcj068

Etxeberria E, Gonzalez P (2003) Evidence for a tonoplast-associated form of sucrose synthase and its potential involvement in sucrose mobilization from the vacuole. J Exp Bot 54:1407-1414. https:// doi.org/10.1093/jxb/erg148

Fedosejevs ET, Ying S, Park J, Anderson EM, Mullen RT, She Y-M, Plaxton WC (2014) Biochemical and molecular characterization of RcSUS1, a cytosolic sucrose synthase phosphorylated in vivo at serine 11 in developing castor oil seeds. J Biol Chem 289:3341233424. https://doi.org/10.1074/jbc.M114.585554

Foyer CH, Valadier M-H, Migge A, Becker TW (1998) Droughtinduced effects on nitrate reductase activity and mrna and on the coordination of nitrogen and carbon metabolism in maize leaves. Plant Physiol 117:283-292. https://doi.org/10.1104/pp.117.1.283

Gamalei YV, van Bel AJE, Pakhomova MV, Sjutkina AV (1994) Effects of temperature on the conformation of the endoplasmic reticulum and on starch accumulation in leaves with the symplasmic minor-vein configuration. Planta 194:443-453. https ://doi.org/10.1007/BF00714455

Guy CL, Huber JL, Huber SC (1992) Sucrose phosphate synthase and sucrose accumulation at low temperature. Plant Physiol 100:502-508

Haigler CH, Ivanova-Datcheva M, Hogan PS, Salnikov VV, Hwang S, Martin K, Delmer DP (2001) Carbon partitioning to cellulose synthesis. Plant Mol Biol 47:29-51. https://doi.org/10.1023/a:10106 15027986

Hanson BA (2017) ChemoSpec: an R package for chemometric analysis of spectroscopic data. Package version 4.4.97. http://cran. nexr.com/web/packages/ChemoSpec/vignettes/ChemoSpec.pdf. Accessed 12 Dec 2017

Hao X, Wang B, Wang L, Zeng J, Yang YJ, Wang XC (2018) Comprehensive transcriptome analysis reveals common and specific genes and pathways involved in cold acclimation and cold stress in tea plant leaves. Sci Hortic 240:354-368. https://doi.org/10.1016/j. scienta.2018.06.008

Hashida Y, Hirose T, Okamura M, Hibara K-i, Ohsugi R, Aoki N (2016) A reduction of sucrose phosphate synthase (SPS) activity affects sucrose/starch ratio in leaves but does not inhibit normal plant growth in rice. Plant Sci 253:40-49. https://doi. org/10.1016/j.plantsci.2016.08.017

Huber SC, Huber JL (1996) Role and regulation of sucrose-phosphate synthase in higher plants. Annu Rev Plant Physiol Plant Mol Biol 47:431-444. https://doi.org/10.1146/annurev.arplant.47.1.431

Ilharco LM, Garcia AR, Lopes da Silva J, Vieira Ferreira LF (1997) Infrared approach to the study of adsorption on cellulose: influence of cellulose crystallinity on the adsorption of benzophenone. Langmuir 13:4126-4132. https://doi.org/10.1021/la962138u

Im KH (2004) Expression of sucrose-phosphate synthase (SPS) in nonphotosynthetic tissues of maize. Mol Cells 17:404-409

Kaplan F, Guy CL (2005) RNA interference of Arabidopsis betaamylase 8 prevents maltose accumulation upon cold shock and increases sensitivity of PSII photochemical efficiency to freezing stress. Plant J 44:730-743. https://doi.org/10.1111/j.1365313X.2005.02565.X

Knudsen KEB, Li BW (1991) Determination of oligosaccharides in protein-rich feedstuffs by gas-liquid chromatography and highperformance liquid chromatography. J Agric Food Chem 39:689694. https://doi.org/10.1021/jf00004a013

Kondo T, Sawatari C (1996) A Fourier transform infra-red spectroscopic analysis of the character of hydrogen bonds in amorphous cellulose. Polymer 37:393-399. https://doi.org/10.1016/00323861(96)82908-9

Kutík J, Hola D, Kočová M, Rothová O, Haisel D, Wilhelmová N, Tichá I (2004) Ultrastructure and dimensions of chloroplasts in leaves of three maize (Zea mays L.) inbred lines and their F1 hybrids grown under moderate chilling stress. Photosynthetica 42:447-455. https://doi.org/10.1023/B:PHOT.0000046165.15048 .a4

Long SP (1983) $\mathrm{C}_{4}$ photosynthesis at low temperatures. Plant Cell Environ 6:345-363. https://doi.org/10.1111/1365-3040.ep116 12141

Lunn JE, Hatch MD (1997) The role of sucrose-phosphate synthase in the control of photosynthate partitioning in Zea mays leaves. Aust J Plant Physiol 24:1-8. https://doi.org/10.1071/PP96088

Lutfiyya LL, Xu N, D’Ordine RL, Morrell JA, Miller PW, Duff SMG (2007) Phylogenetic and expression analysis of sucrose phosphate synthase isozymes in plants. J Plant Physiol 164:923-933. https:// doi.org/10.1016/j.jplph.2006.04.014

Maraña C, García-Olmedo F, Carbonero P (1990) Differential expression of two types of sucrose synthase-encoding genes in wheat in response to anaerobiosis, cold shock and light. Gene 88:167-172. https://doi.org/10.1016/0378-1119(90)90028-P 
Nägele T, Stutz S, Hörmiller II, Heyer AG (2012) Identification of a metabolic bottleneck for cold acclimation in Arabidopsis thaliana. Plant J 72:102-114. https://doi.org/10.1111/j.1365313X.2012.05064.x

Nelson ML, O’Connor RT (1964) Relation of certain infrared bands to cellulose crystallinity and crystal lattice type. Part II. A new infrared ratio for estimation of crystallinity in celluloses I and II. J Appl Polym Sci 8:1325-1341. https://doi.org/10.1002/ app.1964.070080323

Nolte KD, Koch KE (1993) Companion-cell specific localization of sucrose synthase in zones of phloem loading and unloading. Plant Physiol 101:899-905. https://doi.org/10.1104/pp.101.3.899

Núñez JGA, Kronenberger J, Wuillème S, Lepiniec L, Rochat C (2008) Study of AtSUS2 localization in seeds reveals a strong association with plastids. Plant Cell Physiol 49:1621-1626. https://doi. org $/ 10.1093 / \mathrm{pcp} / \mathrm{pcn} 117$

Okamura M, Aoki N, Hirose T, Yonekura M, Ohto C, Ohsugi R (2011) Tissue specificity and diurnal change in gene expression of the sucrose phosphate synthase gene family in rice. Plant Sci 181:159-166. https://doi.org/10.1016/j.plantsci.2011.04.019

Persia D, Cai G, Del Casino C, Faleri C, Willemse MTM, Cresti M (2008) Sucrose synthase is associated with the cell wall of tobacco pollen tubes. Plant Physiol 147:1603-1618. https://doi. org/10.1104/pp.108.115956

Rapacz M, Wolanin B, Hura K, Tyrka M (2008) The effects of cold acclimation on photosynthetic apparatus and the expression of $C O R 14 b$ in four genotypes of barley (Hordeum vulgare) contrasting in their tolerance to freezing and high-light treatment in cold conditions. Ann Bot 101:689-699. https://doi.org/10.1093/aob/ men008

R Core Team (2018) R: a language and environment for statistical computing. R foundation for statistical computing, Vienna, Austria. http://www.R-project.org

Revilla P, Rodríguez VM, Ordás A, Rincent R, Charcosset A, Giauffret C, Melchinger AE, Schön C-C, Bauer E, Altmann T, Brunel D, Moreno-González J, Campo L, Ouzunova M, Álvarez Á, Ruíz de Galarreta JI, Laborde J, Malvar RA (2016) Association mapping for cold tolerance in two large maize inbred panels. BMC Plant Biol 16:127. https://doi.org/10.1186/s12870-016-0816-2

Sage RF, Kubien DS (2007) The temperature response of $C_{3}$ and $C_{4}$ photosynthesis. Plant Cell Environ 30:1086-1106. https://doi.org /10.1111/j.1365-3040.2007.01682.x

Salnikov VV, Grimson MJ, Seagull RW, Haigler CH (2003) Localization of sucrose synthase and callose in freeze-substituted secondary-wall-stage cotton fibers. Protoplasma 221:175-184. https:// doi.org/10.1007/s00709-002-0079-7

Sami F, Yusuf M, Faizan M, Faraz A, Hayat S (2016) Role of sugars under abiotic stress. Plant Physiol Biochem 109:54-61. https:// doi.org/10.1016/j.plaphy.2016.09.005

Savitch LV, Harney T, Huner NPA (2000) Sucrose metabolism in spring and winter wheat in response to high irradiance, cold stress and cold acclimation. Physiol Plant 108:270-278. https://doi.org/ 10.1034/j.1399-3054.2000.108003270.x

Skupień J, Wójtowicz J, Kowalewska Ł, Mazur R, Garstka M, Gieczewska K, Mostowska A (2017) Dark-chilling induces substantial structural changes and modifies galactolipid and carotenoid composition during chloroplast biogenesis in cucumber (Cucumis sativus L.) cotyledons. Plant Physiol Biochem 111:107-118. https ://doi.org/10.1016/j.plaphy.2016.11.022

Sobkowiak A, Jończyk M, Adamczyk J, Szczepanik J, Solecka D, Kuciara I, Hetmanczyk K, Trzcinska-Danielewicz J, Grzybowski
M, Skoneczny M, Fronk J, Sowinski P (2016) Molecular foundations of chilling-tolerance of modern maize. BMC Genomics 17:125. https://doi.org/10.1186/s12864-016-2453-4

Solís-Guzmán MG, Argüello-Astorga G, López-Bucio J, Ruiz-Herrera LF, López-Meza JE, Sánchez-Calderón L, Carreón-Abud Y, Martínez-Trujillo M (2017) Arabidopsis thaliana sucrose phosphate synthase (sps) genes are expressed differentially in organs and tissues, and their transcription is regulated by osmotic stress. Gene Expr Patterns 25-26:92-101. https://doi.org/10.1016/j. gep.2017.06.001

Sowiński P, Dalbiak A, Tadeusiak J, Ochodzki P (1999) Relations between carbohydrate accumulation in leaves, sucrose phosphate synthase activity and photoassimilate transport in chilling treated maize seedlings. Acta Physiol Plant 21:375-381. https://doi. org/10.1007/s11738-999-0009-9

Sowiński P, Rudzińska-Langwald A, Adamczyk J, Kubica I, Fronk J (2005) Recovery of maize seedling growth, development and photosynthetic efficiency after initial growth at low temperature. J Plant Physiol 162:67-80. https://doi.org/10.1016/j.jplph .2004.03.006

Subbaiah CC, Palaniappan A, Duncan K, Rhoads DM, Huber SC, Sachs MM (2006) Mitochondrial localization and putative signaling function of sucrose synthase in maize. J Biol Chem 281:15625-15635. https://doi.org/10.1074/jbc.M600355200

Thalmann M, Santelia D (2017) Starch as a determinant of plant fitness under abiotic stress. New Phytol 214:943-951. https://doi. org/10.1111/nph.14491

Toroser D, Huber SC (1997) Protein phosphorylation as a mechanism for osmotic-stress activation of sucrose-phosphate synthase in spinach leaves. Plant Physiol 114:947-955. https://doi. org/10.1104/pp.114.3.947

von Caemmerer S, Furbank RT (2003) The $\mathrm{C}_{4}$ pathway: an efficient $\mathrm{CO}_{2}$ pump. Photosynth Res 77:191-207. https://doi. org/10.1023/a:1025830019591

Wang AY, Kao MH, Yang WH, Sayion Y, Liu LF, Lee PD, Su JC (1999) Differentially and developmentally regulated expression of three rice sucrose synthase genes. Plant Cell Physiol 40:800-807. https://doi.org/10.1093/oxfordjournals.pcp.a029608

Wang Z, Wei P, Wu M, Xu Y, Li F, Luo Z, Zhang J, Chen A, Xie X, Cao P, Lin F, Yang J (2015) Analysis of the sucrose synthase gene family in tobacco: structure, phylogeny, and expression patterns. Planta 242:153-166. https://doi.org/10.1007/s00425-015-2297-1

Winter H, Huber SC (2000) Regulation of sucrose metabolism in higher plants: localization and regulation of activity of key enzymes. Crit Rev Biochem Mol Biol 35:253-289. https://doi. org/10.1080/10409230008984165

Winter H, Huber JL, Huber SC (1997) Membrane association of sucrose synthase: changes during the graviresponse and possible control by protein phosphorylation. FEBS Lett 420:151-155. https ://doi.org/10.1016/S0014-5793(97)01506-8

Zhang W, Wang J, Huang Z, Mi L, Xu K, Wu J, Fan Y, Ma S, Jiang D (2019) Effects of low temperature at booting stage on sucrose metabolism and endogenous hormone contents in winter wheat spikelet. Front Plant Sci 10:498. https://doi.org/10.3389/ fpls.2019.00498

Publisher's Note Springer Nature remains neutral with regard to jurisdictional claims in published maps and institutional affiliations. 